Canadian

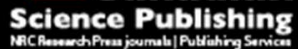

Canadian Journal of Earth Sciences Revue canadienne des sciences de la Terre

\title{
Discussion of "Glacier velocities and dynamic discharge from the ice masses of Baffin Island and Bylot Island, Nunavut, Canada"
}

\begin{tabular}{|r|l|}
\hline Journal: & Canadian Journal of Earth Sciences \\
\hline Manuscript ID & cjes-2016-0179 \\
\hline Manuscript Type: & Discussion \\
\hline Date Submitted by the Author: & 04-Oct-2016 \\
\hline Complete List of Authors: & $\begin{array}{l}\text { Ommanney, C. Simon L.; Scott Polar Reseaerch Institute of Cambridge } \\
\text { University }\end{array}$ \\
\hline Keyword: & $\begin{array}{l}\text { Glaciers, Glacier inventory, Icebergs, Canadian Arctic Archipelago, Baffin } \\
\text { Island }\end{array}$ \\
\hline &
\end{tabular}

SCHOLARONE ${ }^{m}$

Manuscripts 


\section{TITLE PAGE}

Discussion of "Glacier velocities and dynamic discharge from the ice masses of Baffin Island and Bylot Island, Nunavut, Canada"1

C. Simon L. Ommanney

Emeritus Associate

Scott Polar Research Institute

56 Spinney Road

Glenwood, NS B0W 1W0, Canada

e-mail: simon.ommanney@ns.sympatico.ca

\section{Corresponding author}

Simon Ommanney

56 Spinney Road

Glenwood, NS B0W 1W0, Canada

(902) 643-2527

e-mail: simon.ommanney@ns.sympatico.ca

${ }^{1}$ Appears in Canadian Journal of Earth Sciences, 2015, 52(11): 980-989. doi: 10.1139/cjes2015-0087. 
Discussion of "Glacier velocities and dynamic discharge from the ice masses of Baffin Island and Bylot Island, Nunavut, Canada"1

C. Simon L. Ommanney

\begin{abstract}
A similar investigation into calving glaciers and iceberg production on Baffin and Bylot Islands was initiated by the Canadian Government in the 1970s. This is described and reference made to the Glacier Atlas of Canada which, in identifying all individual glaciers in this region of the Canadian Arctic, obviates the need to develop an independent numbering system when individual glaciers need to be identified.
\end{abstract}

Keywords: Glaciers, Glacier Inventory, Icebergs, Canadian Arctic Archipelago, Baffin Island 


\section{Introduction}

The recent paper by Van Wychen et al. (2015) brought to mind a similar study initiated by the Federal Government almost half-a-century ago. This discussion aims to provide some historical perspective in describing what was done, and why.

\section{Discussion}

In 1970, the Glaciology Subdivision of the Department of Energy, Mines and Resources developed an iceberg production survey for Arctic Canada (Løken et al. 1971, 1972). The intent was to inventory all calving, or potentially calving, glaciers that might contribute to the production of icebergs. It included a proposed photogrammetric study of movement rates and the resulting rates of production.

The latter led to the compilation of two manuscript maps of Leffert Glacier, Ellesmere Island, by the Topographic Survey, at scales of 1:10,000 and 1:25,000, plotted from aerial photographs taken in 1959. These provided the framework for investigations by Gerald Holdsworth, who had worked previously on ice flexing and the calving process on Erebus Glacier in the Antarctic (1982). His studies on Ellesmere Island included the Ward Hunt Ice Shelf and d'Iberville Glacier and resulted in reports on tidal interaction with ice fronts and the calving process $(1977,1978)$.

The project had developed in response to increasing activity offshore of Newfoundland, in the Labrador Sea, and concern about the threat to offshore facilities from icebergs. The 
predecessor of Marine and Ice Services, Environment and Climate Change Canada, was interested in determining the sources and production rates of icebergs in Canadian.

By 1970, most of the glaciers in the eastern Arctic, save those in northern Ellesmere Island, had been delineated on aerial photographs, classified and numbered according to the scheme developed for the world glacier inventory (Ommanney, 1971). It was therefore possible to compile a subset of tidewater glaciers and of those with termini $\leq 0.5 \mathrm{~km}$ from the sea. Although our thinking about these matters has changed in light of developments with the climate, at that time our concern was that several years of positive mass balance might lead to the advance of glaciers close to sea level. Evidence from Ellesmere and Axel Heiberg Islands, where the Otto Fiord and Good Friday Bay Glaciers had surged (Hattersley-Smith, 1969; Müller, 1969), meant that glaciers identified as having surge characteristics were also included. The inventory was forwarded to those responsible for the Ice Patrol so a selection of glaciers could be picked for monitoring.

Without high-resolution remote-sensing imagery, and the analytical techniques available through modern GIS, at that time it would have been impossible to duplicate the kind of study reported by Van Wychen et al. (2015). However, we now know that glacier dynamics are affected by meltwater penetrating to the glacier bed so potential advances of the same glaciers, of concern in the 1970s, might still be an issue, albeit for a very different reason. Almut Iken, in her studies on Axel Heiberg Island $(1972,1974)$, was possibly one of the first to document an effect that is now attracting increasing attention (Fitzpatrick, 2013). 
All the glaciers listed in the iceberg production inventory had been assigned unique numbers through the Canadian Glacier Inventory project. Once the identification of individual glaciers in a particular region was completed, the relevant map in the Glacier Atlas of Canada series was published. Those covering Baffin Island are listed in Table 1. These maps have been archived by Natural Resources Canada and are available online at http://geogratis.gc.ca/api/en/nrcan-rncan/ess-sst/-/(urn:iso:series)glacier-atlas-ofcanada. A bound set of the published Atlas maps was deposited in a number of Canadian university libraries (Ommanney, 1989). The availability of this identification scheme means it should have been unnecessary for Van Wychen et al. (2015) to develop the alternative shown in their Table 3. Table 2 lists the equivalent numbers from the Glacier Atlas of Canada that could have been used instead. It is recommended that authors use established glacier inventory numbers to identify unnamed glaciers being discussed in papers, such as has been done previously in this journal, e.g. by Hodgson (1985), rather than proposing new ones. 


\section{References}

Fitzpatrick, A.A.W. and others. 2013. Ice flow dynamics and surface meltwater flux at a land-terminating sector of the Greenland ice sheet. Journal of Glaciology. 59(216): 687696. doi:10.3189/2013JoG12J143.

Hattersley-Smith, G. 1969. Recent observations on the surging Otto Glacier, Ellesmere Island. Canadian Journal of Earth Sciences. 6(4), Part 2, 883-889. doi:10.1139/e69-090.

Hodgson, D.A. 1985. The last glaciation of west-central Ellesmere Island, Arctic Archipelago, Canada. Canadian Journal of Earth Sciences. 22(3): 347-368. doi:10.1139/e85-035.

Holdsworth, G. 1977. Tidal interaction with ice shelves. Annales de Géophysique. 33(1-2): 133-146.

Holdsworth, G. 1978. Some mechanisms for the calving of icebergs. In Husseiny, A.A., ed. Iceberg utilization. Proceedings of the First International Conference and Workshops on Iceberg Utilization for Fresh Water Production, Weather Modification and Other Applications held at Iowa State University, Ames, Iowa, U.S.A., 2-6 October 1977. New York, NY, Pergamon Press, pp. 160-175.

Holdsworth, G. 1982. Dynamics of Erebus Glacier tongue. Annals of Glaciology. 3: 131-137. Iken, A. 1972. Measurements of water pressure in moulins as part of a movement study of the White Glacier, Axel Heiberg Island, Northwest Territories, Canada. Journal of Glaciology. 11(61): 53-58. doi:. 
Iken, A. 1974. Velocity fluctuations of an Arctic valley glacier; a study of the White Glacier, Axel Heiberg Island, Canadian Arctic Archipelago. Montréal, Que., McGill University. (Axel Heiberg Island Research Reports Glaciology 5).

Løken, O. H., Ommanney, C. S. L., and Holdsworth, G. 1972. Iceberg studies in the Glaciology Division, Environment Canada. In Karlsson, T., ed. Sea Ice, Proceedings of an International Conference, 10-13 May 1971, Reykjavík, Iceland. Reykjavík, Iceland, National Research Council, pp. 146-151.

Løken, O. H., Ommanney, C. S. L., Holdsworth, G., and Arnold, K. C. 1971. Iceberg studies in the Glaciology Subdivision. Proceedings, Canadian Seminar on Icebergs, 6-7 December 1970. Halifax, N.S., Department of National Defence. Maritime Command Headquarters, pp. 128-134.

Müller, F. 1969. Was the Good Friday glacier on Axel Heiberg Island surging? Canadian Journal of Earth Sciences. 6(4), Part 2: 891-894. doi:10.1139/e69-091.

Ommanney, C.S.L. 1971. The Canadian glacier inventory. Glaciers, Proceedings of Workshop Seminar 1970, 24-25 September 1970, Vancouver, B.C. Ottawa, Ont., Canadian National Committee for the International Hydrological Decade, pp. 23-30.

Ommanney, C.S.L. 1989. Glacier Atlas of Canada. Limited edition. Saskatoon, Sask., Environment Canada. National Hydrology Research Institute. Scientific Information Division. 2 pp. +52 maps.

Van Wychen, W., Copland, L., Burgess, D.O., Gray, L., and Schaffer, N. 2015. Glacier velocities and dynamic discharge from the ice masses of Baffin Island and Bylot Island, Nunavut, 
Canada. Canadian Journal of Earth Sciences. 52(11): 980-989. doi:10.1139/cjes-2015-

0087. 
Table 1. Glacier Atlas maps of Baffin and Bylot Islands.

\begin{tabular}{|c|c|c|c|c|c|}
\hline 5.0 & Baffin Island index & 5.9 & Barnes Ice Cap & 5.18 & Hoare Bay \\
\hline 5.1 & Bylot Island & 5.1 & Gibbs Fiord & 5.19 & Kingnait Fiord \\
\hline 5.2 & Brodeur Peninsula & 5.11 & Sam Ford Fiord & 5.2 & Penny Ice Cap \\
\hline 5.3 & Borden Peninsula West & 5.12 & Clyde Inlet & 5.21 & Popham Bay \\
\hline 5.4 & Borden Peninsula East & 5.13 & McBeth Fiord & 5.22 & Beekman Peninsula \\
\hline 5.5 & Milne Inlet & 5.14 & Home Bay & 5.23 & Blunt Peninsula \\
\hline 5.6 & Tay Sound & 5.15 & Okoa Bay & 5.24 & Meta Incognita Peninsula \\
\hline 5.7 & Pond Inlet & 5.16 & Coronation Fiord & & \\
\hline 5.8 & Cambridge Fiord & 5.17 & Padle Fiord & & \\
\hline
\end{tabular}

Table 2. Glacier inventory equivalents for IDs in Wychen et al. (2015) Table 3.

\begin{tabular}{ccccccccc}
\hline Gl. ID & Invent No. & Atlas & Gl. ID & Invent No. & Atlas & Gl. ID & Invent No. & Atlas \\
\hline 1 & $46203 \mathrm{H} 65$ & 5.11 & 17 & $46202 \mathrm{R} 82$ & 5.8 & 33 & $46202 \mathrm{P} 22$ & 5.7 \\
2 & $46203 \mathrm{H} 64$ & 5.11 & 18 & $46202 \mathrm{R} 147$ & 5.8 & 34 & $46202 \mathrm{P} 58$ & 5.7 \\
3 & $46203 \mathrm{H} 103$ & 5.11 & 19 & $46202 \mathrm{Q} 30$ & 5.7 & 35 & $46202 \mathrm{G} 46$ & 5.4 \\
4 & $46204 \mathrm{P} 47$ & 5.17 & 20 & $46202 \mathrm{Q} 100$ & 5.7 & 36 & $46202 \mathrm{G} 48$ & 5.4 \\
5 & $46203 \mathrm{~J} 62$ & 5.12 & 21 & $46202 \mathrm{P} 75$ & 5.7 & 37 & $46203 \mathrm{~L} 60$ & 5.13 \\
6 & $46203 \mathrm{I} 92$ & 5.12 & 22 & $46202 \mathrm{P} 10$ & 5.7 & 38 & $46203 \mathrm{~K} 36$ & 5.13 \\
7 & $46203 \mathrm{E} 60$ & 5.11 & 23 & $46202 \mathrm{Q} 101$ & 5.7 & 39 & $46202 \mathrm{~T} 6$ & 5.8 \\
8 & $46203 \mathrm{E} 57$ & 5.11 & 24 & $46202 \mathrm{Q} 96$ & 5.7 & 40 & $46202 \mathrm{~T} 3$ & 5.8 \\
9 & $46203 \mathrm{E} 54$ & 5.11 & 25 & $46202 \mathrm{P} 61$ & 5.7 & 41 & $46202 \mathrm{~S} 18$ & 5.8 \\
10 & $46203 \mathrm{E} 11$ & 5.11 & 26 & $46202 \mathrm{P} 11$ & 5.7 & 42 & $46202 \mathrm{~T} 72$ & 5.8 \\
11 & $46203 \mathrm{C} 84$ & 5.10 & 27 & $46202 \mathrm{P} 80$ & 5.7 & 43 & $46204 \mathrm{I37}$ & 5.15 \\
12 & $46203 \mathrm{~V} 136$ & 5.10 & 28 & $46202 \mathrm{M} 123$ & 5.7 & 44 & $46204 \mathrm{~L} 75$ & 5.16 \\
13 & $46203 \mathrm{~V} 135$ & 5.10 & 29 & $46202 \mathrm{M} 7$ & 5.7 & 45 & $46201 \mathrm{D} 45$ & 5.1 \\
14 & $46203 \mathrm{~V} 129$ & 5.10 & 30 & $46202 \mathrm{P} 83$ & 5.7 & 46 & $46201 \mathrm{D} 119$ & 5.1 \\
15 & $46203 \mathrm{~V} 124$ & 5.10 & 31 & $46202 \mathrm{P} 7$ & 5.7 & & & \\
16 & $46202 \mathrm{Q} 18$ & 5.7 & 32 & $46202 \mathrm{P} 8$ & 5.7 & & & \\
\hline
\end{tabular}

